\title{
Implementasi Metode Six Sigma dan Internal Audit dalam Menjamin Kualitas Produk Pada PT X untuk Mengefisiensikan Biaya Kualitas
}

\author{
Gita Permata Liansari ${ }^{1 *}$ \\ 1*) Fakultas Teknologi Industri, Jurusan Teknik Industri, \\ Institut Teknologi Nasional \\ Jl. Penghulu K.H. Hasan Mustafa No. 23 Bandung 40124 \\ email : gitapermatalitenas.ac.id
}

\begin{abstract}
Abstrak
PT $X$ adalah perusahaan garment berskala internasional, dimana $80 \%$ produknya dikirim ke beberapa negara di benua Eropa. Loyalitas konsumen dalam hal ini salah satunya dibangkitkan dengan menghasilkan produk yang berkualitas. Produk yang berkualitas adalah produk yang spesifikasinya memenuhi atau merepresentasikan kebutuhan dan keinginan konsumen. Oleh sebab itu setiap perusahaan harus selalu menghasilkan produk yang berkualitas sehingga loyalitas konsumennya dapat semakin meningkat dan jangkauan pasar perusahaan tersebut juga dapat semakin meluas. Berdasarkan data tahun 2010 diketahui bahwa $80 \%$ produk cacat pada PT X disebabkan oleh cacat jahitan, diantaranya jahitan putus, jahitan loncat, dan jahitan longgar. Tujuan penelitian ini adalah memberikan usulan perbaikan terhadap PT X dengan menerapkan metode Six Sigma dan Konsep Internal Audit, dalam upaya menjamin kualitas produk yang dihasilkan dan mengefisiensikan biaya kegagalan dalam produksi pada PT X. Internal audit merupakan faktor kritis untuk pencapaian kesuksesan dalam bisnis. Dalam internal audit, PT X dapat melakukan pengendalian proses, pengendalian dokumen, pengendalian peraturan, serta kebijakan perusahaan. Dari hasil penelitian diperoleh nilai DPMO (Defect per Million Opportunities)sebelum implementasi perbaikan adalah 6429 dengan nilai sigma adalah 3,987 $\sigma$. Sedangkan nilai DPMO setelah implementasi perbaikan adalah 2431 dan nilai sigma adalah 4,308 $\sigma$. Penghematan yang diperoleh perusahaan jika menerapkan usulan perbaikan diperkirakan Rp 117.775.525,90 atau setara dengan memproduksi 1.145 unit produk berkualitas.
\end{abstract}

Kata Kunci: Six Sigma, Internal Audit, Biaya Kualitas, Biaya Kegagalan dalam Produksi, Industri Garment

\section{Pendahuluan}

Kualitas merupakan hal penting yang harus selalu menjadi patokan perusahaan dalam melakukan proses produksinya. Dengan kualitas sebenarnya dapat menggambarkan mampu atau tidaknya perusahaan tersebut mencapai kepuasan konsumennya. Perusahaan yang mampu mencapai kepuasan konsumen adalah perusahaan yang mampu menghasilkan produk-produk yang mampu merepresentasikan keinginan konsumen.

Kualitas juga sangat erat kaitannya dengan

*Korespondensi Penulis loyalitas konsumen. Semakin mampu perusahaan menghasilkan produk yang berkualitas, maka konsumen akan semakin loyal terhadap perusahaan tersebut. Pada umumnya konsumen yang puas akan mampu mempengaruhi sebanyak 3-4 orang calon konsumen untuk membeli produk dari perusahaan tersebut. Sebaliknya jika konsumen tidak puas terhadap produk yang dihasilkan suatu perusahaan, maka konsumen yang tidak puas tersebut akan menyampaikan ketidakpuasan tersebut kepada 11-12 calon konsumen lainnya. Jadi jika seseorang merasakan pelayanan dibawah harapannya maka pelanggan akan mening- 
galkan perusahaan itu (Kotler, 2003). Dalam hal ini, sangat jelas bahwa loyalitas konsumen dapat dicapai oleh suatu perusahaan, jika perusahaan tersebut mampu menghasilkan produk yang berkualitas, maka konsumen akan puas dan secara tidak langsung akan menyampaikan kepuasannya itu kepada orang disekitarnya, dengan kata lain hal ini akan mampu memperluas jangkauan pasar dari perusahaan tersebut.

PT X adalah perusahaan garment berskala internasional karena $80 \%$ produk yang diproduksinya dikirimkan ke beberapa negara di Benua Eropa. Namun walaupun produknya sebagian besar adalah produk yang di-eksport, namun masih terdapat beberapa permasalahan terkait dengan kualitas produk. Hampir sekitar $80 \%$ cacat produk yang terjadi di PT X disebabkan oleh cacat jahitan, seperti: jahitan putus, jahitan loncat, dan jahitan longgar. Pada PT X telah terdapat departemen khusus yang menjamin kualitas produk telah sesuai dengan standar sebelum sampai ke tangan konsumen, namun cacat produk masih saja sering terjadi. Personil-personil dari departemen QA (Quality Assurance) bertugas untuk melakukan pemeriksaan terhadap produk dan mengklasifikasikan cacat produk yang ditemukan ke dalam 2 kategori, yaitu cacat produk rework atau cacat produk reject.

Jika cacat produk diklasifikasikan sebagai cacat produk rework, maka perusahaan harus mengeluarkan biaya tambahan untuk melakukan perbaikan ulang sehingga produk masih dapat dijual kepada konsumen. Namun jika cacat produk diperiksa dan kemudian diklasifikasikan dalam kategori cacat produk reject, maka produk reject tersebut akan dipisahkan dan disimpan ke gudang barang reject. Ditemukannya produk reject pada PT X masih saja sering terjadi dan sangat jelas ini akan memberikan dampak kerugian dari segi finansial bagi PT X. Berikut ditampilkan proporsi unsur-unsur biaya kualitas yang sering terjadi pada perusahaan:

Berdasarkan Tabel 1 diketahui bahwa proporsi biaya kualitas pada perusahaan paling tertinggi yaitu sebesar 4,01\% dari total biaya penjualan disebabkan oleh biaya kegagalan internal, yaitu biaya yang muncul pada perusahaan akibat produk diidentifikasi sebagai produk dengan cacat rework atau cacat reject. Biaya kegagalan internal merupakan biaya yang muncul karena perusahaan mengidentifikasi produk cacat setelah produk tersebut sampai ke tangan konsumen (Gaspersz, 2006). Pada Tabel 1 diperoleh bahwa penyebab utama dari biaya kegagalan internal adalah biaya yang dise-
Tabel 1: Proporsi biaya kualitas terhadap biaya penjualan

\begin{tabular}{|c|c|c|c|}
\hline Unsur Biaya & $\begin{array}{l}\% \text { dari } \\
\text { pen- } \\
\text { jualan }\end{array}$ & $\begin{array}{l}\text { Sub Bagian } \\
\text { paling } \\
\text { Dominan }\end{array}$ & $\begin{array}{c}\% \text { dari } \\
\text { pen- } \\
\text { jualan }\end{array}$ \\
\hline $\begin{array}{c}\text { Biaya } \\
\text { Pencegahan }\end{array}$ & 0,70 & $\begin{array}{l}\text { Perancangan } \\
\text { Kualitas }\end{array}$ & 0,32 \\
\hline $\begin{array}{c}\text { Biaya } \\
\text { Pengujian }\end{array}$ & 1,60 & $\begin{array}{l}\text { Kegiatan } \\
\text { Inspeksi }\end{array}$ & 0,70 \\
\hline $\begin{array}{c}\text { Biaya } \\
\text { Kegagalan } \\
\text { Internal }\end{array}$ & 4,01 & $\begin{array}{c}\text { Rework dan } \\
\text { Reject }\end{array}$ & 3,90 \\
\hline $\begin{array}{c}\text { Biaya } \\
\text { Kegagalan } \\
\text { Eksternal }\end{array}$ & 1,01 & $\begin{array}{l}\text { Keluhan } \\
\text { Pemakai }\end{array}$ & 0,80 \\
\hline
\end{tabular}

babkan karena terdapat produk dengan cacat rework dan cacat reject sebesar 3,90\% dari total $4,01 \%$ yang mempengaruhi penjualan pada perusahaan.

Dengan kata lain, bahwa semakin perusahaan mampu menghasilkan produk berkualitas, maka perusahaan akan mampu memperoleh keuntungan dalam kegiatan produksinya. Oleh sebab itu, penting bagi perusahaan untuk tetap mempertahankan dalam kegiatan produksinya menghasilkan produksi yang sesuai dengan spesifikasi dari kebutuhan dan keinginan konsumennya.

Pada umumnya kemampuan perusahaan untuk menghasilkan produk yang berkualitas sangat erat kaitannya dengan kemampuan perusahaan tersebut untuk mengatur sistem manajemen mutu yang baik bagi perusahaan. Sistem Manajemen Mutu adalah sekumpulan prosedur terdokumentasi dan praktek-praktek standar untuk manajemen sistem yang bertujuan menjamin kesesuaian dari suatu proses dan produk (barang atau jasa) terhadap kebutuhan persyaratan tertentu yang ditentukan oleh pelanggan dan organisasi (Gaspersz, 2008). Salah satu bentuk pengontrolan perusahaan adalah dengan melakukan internal audit untuk mengidentifikasi prosedur, report, dan kebijakan yang tersedia dan konsisten berjalan di perusahaan. Pada Tabel 2 berikut ditampilkan Industri-industri yang melakukan internal audit sebagai upaya menjamin sistem manajemen mutu perusahaan untuk menjamin produk yang dihasilkannya adalah produk yang berkualitas

Sangat pentingnya keseriusan perusahaan untuk memperhatikan dan mempertahan sistem manajemen mutu perusahaan dengan internal audit, pada dasarnya merupakan langkah awal keseriusan perusahaan dalam upaya memperhatikan produk yang dihasilkannya berkualitas. Oleh sebab itu pada penelitian ini dite- 
Tabel 2: Hasil penelitian mengenai industri yang melakukan internal audit (CBOK, 2010)

\begin{tabular}{|c|c|c|}
\hline Jenis Industri & Ya & Tidak \\
\hline $\begin{array}{c}\text { Industri keuangan, meliputi: } \\
\text { perbankan, asuransi, dan real estate }\end{array}$ & $26 \%$ & $74 \%$ \\
\hline Manufaktur dan konstruksi & $19 \%$ & $81 \%$ \\
\hline $\begin{array}{c}\text { Transportasi, komunikasi, listrik, } \\
\text { minyak, dan pelayanan kesehatan }\end{array}$ & $34 \%$ & $66 \%$ \\
\hline Jasa & $21 \%$ & $79 \%$ \\
\hline Sektor publik atau kepemerintahan & $42 \%$ & $58 \%$ \\
\hline Lainnya & $23 \%$ & $77 \%$ \\
\hline Raw material dan pertanian & $15 \%$ & $85 \%$ \\
\hline Perdagangan & $18 \%$ & $82 \%$ \\
\hline Rata-rata keseluruhan & $26 \%$ & $74 \%$ \\
\hline
\end{tabular}

rapkan Metode Six Sigma untuk mengetahui performansi awal PT X dan memberikan solusi perbaikan dan menerapkan konsep internal audit. Selain itu dihitung juga biaya kegagalan dalam produksi untuk memperkirakan penghematan yang dapat diterima perusahaan seandainya PT X mampu memperhatikan kualitas dari awal kegiatan produksinya. Penghematan ini tentu akan memberikan keuntungan dari segi finansial, selain keuntungan jangkauan pangsa pasar dan kepuasan konsumen yang juga akhirnya tercapai jika produk yang diproduksi PT X adalah produk berkualitas.

\section{Studi Literatur}

\subsection{Definisi Kualitas}

Beberapa definisi kualitas menurut para ahli, diantaranya:

1. Juran dalam Ariani (2002) menyatakan bahwa mutu adalah kesesuaian dengan tujuan dan manfaatnya.

2. Scherkenbach dalam Ariani (2002) menyatakan bahwa mutu ditentukan oleh pelanggan. Pelanggan menginginkan produk yang sesuai dengan kebutuhan dan harapannya pada suatu tingkat harga tertentu yang menunjukan nilai dari produk tersebut.

3. Elliot dalam Ariani (2002) menyatakan bahwa mutu adalah sesuatu yang berbeda untuk orang yang berbeda dan tergantung pada waktu dan tempat atau dikatakan sesuai dengan tujuan.

4. Standar Nasional Indonesia dalam Ariani (2002) mendefinisikan mutu sebagai keseluruhan ciri dan karakteristik produk atau jasa yang kemampuannya dapat memuaskan kebutuhan, baik yang dinyatakan secara tegas maupun tersamar.
5. Crosby dalam Nasution (2004) menyatakan bahwa mutu adalah conformance to requirement, yaitu sesuai dengan yang disyaratkan atau distandarkan. Suatu produk memiliki mutu apabila sesuai dengan standar mutu yang telah ditentukan. Standar mutu meliputi bahan baku, proses produksi dan produk jadi.

6. Deming dalam Nasution (2004) menyatakan bahwa mutu adalah kesesuaian dengan kebutuhan pasar atau konsumen. Perusahaan harus benar-benar dapat memahami apa yang dibutuhkan konsumen atas suatu produk yang akan dihasilkan.

7. Feigenbaun dalam Nasution (2004) menyatakan bahwa mutu adalah kepuasan pelanggan sepenuhnya (full customer satisfaction). Suatu produk bermutu apabila dapat memberikan kepuasan sepenuhnya kepada konsumen, yaitu sesuai dengan apa yang diharapkan konsumen atas suatu produk.

8. Garvin dan Daviz dalam Nasution (2004) menyatakan bahwa mutu adalah suatu kondisi dinamis yang berhubungan dengan produk, manusia atau tenaga kerja, proses dan tugas serta lingkungan yang memenuhi atau melebihi harapan pelanggan atau konsumen.

Dengan demikian kualitas merupakan representasi dari produk yang dihasilkan perusahaan. Produk berkualitas adalah produk yang memenuhi spesifikasi dari kebutuhan dan keinginan konsumen. Produk yang berkualitas akan memunculkan loyalitas dari konsumen dan memperluas pangsa pasar dari produk tersebut. Oleh sebab itu, sangat penting bagi perusahaan untuk berusaha memproduksi dan mempertahankan untuk menghasilkan produk yang berkualitas disepanjang proses produksi yang dilakukannya.

\subsection{Dimensi Kualitas}

Menurut Garvin 8 dimensi kualitas (Gaspersz, 1997), diantaranya:

1. Performance yaitu kesesuaian produk dengan fungsi utama produk itu sendiri atau karakteristik operasi dari suatu produk.

2. Feature yaitu ciri khas produk yang membedakan dengan produk lainnya dan merupakan karakteristik pelengkap dan mampu menimbulkan kesan yang baik bagi pelanggan. 
3. Reliability yaitu kepercayaan pelanggan terhadap produk karena kehandalannya atau kemungkinan rusaknya rendah.

4. Conformance to Standard yaitu kesesuaian produk dengan syarat atau ukuran tertentu atau sejauh mana karakteristik desain dan operasi memenuhi standar yang telah ditetapkan.

5. Durability yaitu tingkat keawetan produk atau lama umur produk.

6. Serviceability yaitu kemudahan produk bila akan diperbaiki atau kemudahan memperoleh komponen produk tersebut.

7. Aesthetics yaitu keindahan atau daya tarik produk.

8. Perception yaitu fanatisme konsumen akan merk suatu produk tertentu karena citra atau reputasi produk itu sendiri.

Dimensi-dimensi kualitas ini mengindikasikan hal-hal yang dapat menjadi pertimbangan bagi suatu perusahaan untuk menghasilkan produk yang berkualitas. Dengan kata lain, dimensi kualitas merupakan ukuran penentu suatu produk atau jasa dapat dikatakan berkualitas atau tidak berkualitas. Semakin banyak dimensi ini dipenuhi, maka suatu produk atau jasa dapat dikatakan bermutu (Dermawan, 2007).

\subsection{Biaya Kualitas}

Biaya-biaya kualitas (Gaspersz, 2003), diantaranya sebagai berikut:

\section{Biaya Pencegahan} Merupakan biaya yang muncul ketika perusahaan melakukan pencegahan dalam menghasilkan produk yang tidak berkualitas. Biaya ini adalah biaya yang dikeluarkan oleh perusahaan untuk membuat produk sesuai dengan spesifikasi dari kebutuhan dan keinginan konsumen. Contoh biaya-biaya pencegahan pada perusahaan diantaranya: biaya pelatihan kualitas, biaya rekayasa ulang kualitas, biaya perencanaan kualitas, biaya audit kualitas, biaya pengkajian kualitas, biaya perancangan produk, dan lain-lain. Biaya ini adalah biaya yang muncul diawal sebelum proses produksi dilakukan, dengan tujuan untuk menghasilkan produk sesuai dengan kebutuhan dan keinginan konsumen.

2. Biaya Pengujian atau Biaya Pemeriksaan Merupakan biaya yang muncul pada perusahaan ketika perusahaan melakukan pengujian terhadap produk yang dihasilkannya. Pengujian ini dilakukan sebagai upaya pencegahan produk yang tidak berkualitas sebelum sampai ke tangan konsumen. Selain itu biaya pengujian ini merupakan biaya yang muncul karena perusahaan melakukan identifikasi terhadap produk yang memenuhi dan atau tidak memenuhi spesifikasi yang ditentukan. Contoh biaya pengujian adalah biaya inspeksi dan biaya pengujian produk.

\section{Biaya Kegagalan Internal}

Merupakan biaya yang muncul karena perusahaan mengidentifikasi produk cacat sebelum produk tersebut sampai ke tangan konsumen. Contoh biaya kegagalan internal, diantaranya: biaya rework, biaya reject, biaya sisa bahan, biaya pengujian ulang, dan lain-lain.

\section{Biaya Kegagalan Eksternal}

Merupakan biaya yang muncul karena perusahaan mengidentifikasi produk cacat setelah produk tersebut sampai ke tangan konsumen. Jadi biaya ini akan muncul karena muncul komplain atau keluhan dari pihak konsumen akibat produk yang diterimanya adalah produk yang tidak sesuai dengan spesifikasi yang ditentukan oleh konsumen. Contoh biaya kegagalan eksternal, diantaranya: biaya retur produk, biaya garansi, biaya perbaikan dan biaya ongkos kirim produk yang dikembalikan, biaya penanganan keluhan konsumen, dan lain-lain.

\subsection{Six Sigma}

Metode Six Sigma merupakan metode yang menentukan target kualitas bagi perusahaan. Metode ini diterapkan pada perusahaan Motorola sejak tahun 1986 dan merupakan terobosan baru dalam bidang manajemen mutu (Gaspersz, 2003). Metode Six Sigma menetapkan 3,4 kegagalan per satu juta kesempatan untuk menghasilkan produk. Jika perusahaan menghasilkan cacat sebesar 3,4 dari satu juta produk yang diproduksi, maka perusahaan tersebut berhasil mencapai nilai sigma adalah $6 \sigma$. Semakin sulitnya perusahaan mencapai $6 \sigma$ tersebut merupakan tantangan bagi perusahaan untuk mampu menghasilkan produk yang berkualitas, atau dengan kata lain adalah menghasilkan produk yang sesuai dengan spesifikasi yang ditentukan oleh pihak konsumen. Perusahaan yang mampu mencapai $6 \sigma$ merupakan perusahaan yang hanya membuat 3,4 cacat dari 
satu juta produk yang diproduksi oleh perusahaan tersebut.

\subsubsection{Tahapan Metode Six Sigma}

Tahapan-tahapan dalam Metode Six Sigma, diantaranya:

1. Define merupakan tahapan awal dari metode Six Sigma. Pada tahap ini diidentifikasi jenis-jenis cacat yang terjadi pada perusahaan. Selain itu, pada tahap ini diidentifikasi tahapan-tahapan proses produksi yang dialami suatu produk.

2. Measure merupakan tahapan selanjutnya dari proses define. Pada tahap ini dilakukan pengukuran performansi perusahaan sebelum implementasi perbaikan. Tahapan ini bertujuan untuk mengetahui level sigma dan nilai DPMO perusahaan sebelum dilakukan perbaikan.

3. Analyze merupakan tahapan selanjutnya setelah tahapan define dan tahapan measure. Pada tahap ini, dilakukan analisa penyebab-penyebab dari kecacatan produk yang muncul dalam proses produksi. Tujuan dari tahapan ini adalah mengidentifkasi akar permasalahan dari cacat-cacat produk yang terjadi pada perusahaan.

4. Improve merupakan tahapan selanjutnya setelah tahapan analyze. Seperti yang telah dijelaskan bahwa pada tahapan analyze dilakukan identifikasi penyebab permasalahan cacat produk yang terjadi pada perusahaan, maka pada tahap improve ini dilakukan perancangan usulan-usulan perbaikan yang menjadi akar permasalahan perusahaan mampu menghasilkan produk yang tidak bekualitas.

5. Control merupakan tahapan akhir dari siklus Six Sigma. Pada tahapan ini dilakukan pengendalian terhadap sistem perusahaan terkait dengan kemampuannya untuk tetap bertahan menghasilkan produk yang berkualitas.

\subsection{Peran Internal Audit}

Terdapat 4 peran internal audit bagi perusahaan, diantaranya (Xiangdong, 1997)

1. Pengawasan, pencegahan, dan perlindungan

Internal audit mengawasi departemen dan perusahaan untuk memenuhi kebijakan, hukum, dan peraturan, mencegah kehilangan aset, menghindari kesalahan, dan menjamin integritas.
2. Promosi

Internal audit menguatkan manajemen perusahaan, memajukan teknologi produksi, mengurangi biaya produksi, dan memperbaiki keuntungan ekonomi bisnis.

3. Evaluasi dan sertifikasi

Internal audit mengevaluasi dan menyertifikasi produksi perusahaan, menghitung pendapatan dan pengeluaran, dan mengevaluasi pertanggung-jawaban ekonomi bisnis dan aktivitas-aktivitas ekonomi.

4. Konsultasi Internal audit menyediakan pemimpin perusahaan dengan cukup, tepat waktu, dan akurat dalam membantu membuat keputusan utama.

\subsection{Lingkup Internal Audit}

Pada Tabel 3 menunjukkan hasil penelitian yang dilakukan oleh CBOK (Common Body of Knowledge) dalam meneliti aktivitas-aktivitas yang diaudit oleh internal auditor di tahun 2010. CBOK survey juga meneliti aktivitas yang diprediksi akan di-audit dalam internal audit selama 5 tahun kedepan (Tahun 2011 s/d 2015).

Tabel 3: Persentase aktivitas internal audit (CBOK, 2010)

\begin{tabular}{|c|c|c|}
\hline \multirow{2}{*}{ Aktivitas Internal Audit } & \multicolumn{2}{|c|}{ Tahun 2010 } \\
\cline { 2 - 3 } & Persentase (\%) & Peringkat \\
\hline Operational audits & $88.9 \%$ & 1 \\
\hline $\begin{array}{c}\text { Audits of compliance with } \\
\text { regulatory code (including } \\
\text { privacy) requirements }\end{array}$ & $75.1 \%$ & 2 \\
\hline Auditing of financial risks & $71,6 \%$ & 3 \\
\hline $\begin{array}{c}\text { Investigations of fraud and } \\
\text { irregularities }\end{array}$ & $71,2 \%$ & 4 \\
\hline $\begin{array}{c}\text { Evaluating effectiveness of } \\
\text { control systems }\end{array}$ & $68,8 \%$ & 5 \\
\hline
\end{tabular}

Pada Tabel 4 ditampilkan hasil penelitian terhadap prediksi 5 aktivitas yang akan di-audit dalam internal audit untuk 5 tahun kedepan.

Tabel 4: Prediksi Persentase Aktivitas Internal Audit 5 Tahun Kedepan (CBOK, 2010)

\begin{tabular}{|c|c|c|}
\hline \multirow{2}{*}{ Aktivitas Internal Audit } & \multicolumn{2}{|c|}{ Prediksi (Tahun 2011 2015) } \\
\cline { 2 - 3 } & Persentase (\%) & Peringkat \\
\hline $\begin{array}{c}\text { Corporate governance } \\
\text { reviews }\end{array}$ & $23,0 \%$ & 1 \\
\hline $\begin{array}{c}\text { Audits of enterprise risk } \\
\text { management processes }\end{array}$ & $20,4 \%$ & 2 \\
\hline $\begin{array}{c}\text { Review addressing linkage of } \\
\text { strategy and company } \\
\text { performance (example: } \\
\text { balanced scorecard) }\end{array}$ & $19,9 \%$ & 3 \\
\hline Ethics audits & $19,3 \%$ & 4 \\
\hline Migration to IFRS & $18,8 \%$ & 5 \\
\hline
\end{tabular}




\subsection{Siklus Internal Audit}

Pada Gambar 1 ditampilkan siklus internal audit yang dilakukan oleh internal auditor dalam melakukan internal audit.

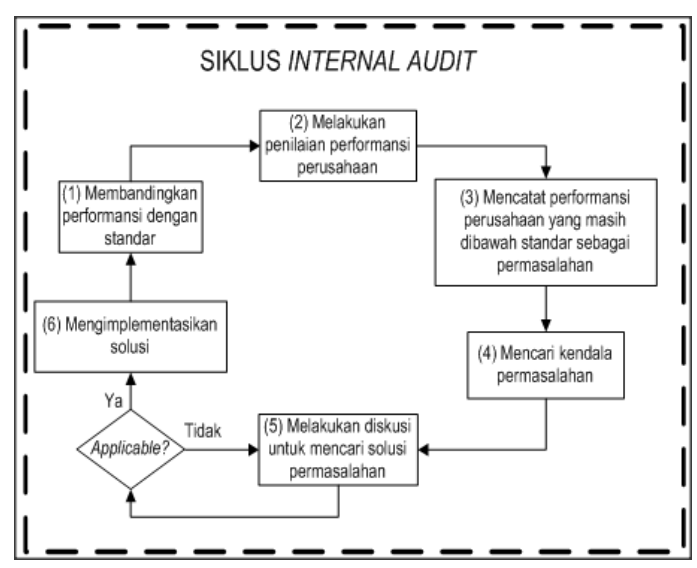

Gambar 1: Siklus Aktivitas Internal Audit Sumber: Permata, 2012

\section{Metodologi Penelitian}

Pada Gambar 2 di Lampiran ditampilkan bagan metodologi penelitian. Dalam penelitian ini digunakan Metode Six Sigma, konsep Internal Audit, dan konsep Biaya Kualitas.

\section{Pengumpulan dan Pengola- han Data}

\subsection{Tahap Define}

Berdasarkan pengumpulan data yang dilakukan pada periode Januari-Desember 2010, diketahui terdapat jenis-jenis cacat yang terjadi pada PT X, diantaranya:

1. Warna pada panel garment belang,

2. Aksesoris yang dipasang salah,

3. Aksesoris pada garment kurang kuantitasnya,

4. Ukuran garment tidak sesuai spesifikasi,

5. Interlining terkelupas, kancing lepas, ditemukan batu (untuk efek washing / stonewash) tertinggal didalam kantong (pocket),

6. Jahitan Putus,

7. Jahitan Longgar,

8. Jahitan Loncat, dan

9. Jahitan Meleset
Jenis-jenis cacat tersebut pada umumnya menjadi masalah pada PT $X$ sehingga mendapatkan komplain dari para konsumennya.

\subsection{Tahap Measure}

Pada Tabel 5 ditampilkan Data Produksi dan Rekapitulasi Jumlah Cacat pada PT X selama periode bulan Januari-Desember 2010.

Tabel 5: Hasil penelitian mengenai industri yang melakukan internal audit (CBOK, 2010)

\begin{tabular}{|c|c|c|c|}
\hline $\begin{array}{c}\text { Periode } \\
\text { Bulan }\end{array}$ & $\begin{array}{c}\text { Jumlah } \\
\text { Produksi } \\
\text { (unit) }\end{array}$ & Jumlah Cacat & $\begin{array}{c}\text { Proporsi } \\
\text { Cacat (\%) }\end{array}$ \\
\hline Jan 2010 & 34082 & 2507 & 0.81731 \\
Feb 2010 & 35038 & 2394 & 0.759176 \\
\hline Maret 2010 & 46280 & 2917 & 0.700327 \\
\hline April 2010 & 45082 & 2491 & 0.613943 \\
\hline Mei 2010 & 43028 & 2321 & 0.599351 \\
\hline Juni 2010 & 46293 & 2284 & 0.548199 \\
\hline Juli 2010 & 42018 & 2745 & 0.725879 \\
\hline Agst 2010 & 42846 & 2198 & 0.57 \\
\hline Sept 2010 & 45348 & 2490 & 0.610097 \\
\hline Okt 2010 & 29005 & 1502 & 0.57538 \\
\hline Nov 2010 & 31354 & 1355 & 0.48018 \\
\hline Des 2010 & 40018 & 2592 & 0.719676 \\
\hline TOTAL & 480392 & 27794 & 0,643293 \\
\hline
\end{tabular}

Perhitungan DPO dan DPMO sebelum perbaikan:

$$
D P O=\frac{\text { jumlahdefect }}{\text { Peluangcacat }(C T Q) x \text { jumlahsample }}
$$

$$
D P O=\frac{27794}{9 \times 480392}=0,006428546317
$$

$$
D P M O=D P O x 1.000 .000=6429
$$

Berdasarkan perhitungan, nilai DPMO untuk PT X pada periode Januari-Desember 2010 adalah 6.429, dengan nilai konversi sigmanya adalah 3,987 $\sigma$.

\subsection{Tahap Analyze}

\subsubsection{Penentuan Prioritas Perbaikan}

Pada Gambar 3 ditampilkan histogram persentase produk cacat pada periode bulan JanuariDesember 2010. Jumlah cacat paling banyak terjadi pada bulan Januari, Februari, Juli, dan Desember berada pada level diatas $0,7 \%$.

Pada Gambar 4 ditampilkan rata-rata jenis cacat yang terjadi pada bulan Januari, Februari, Juli, dan Desember 2010. Prioritas cacat ditentukan berdasarkan cacat produk yang paling sering terjadi pada 4 periode tersebut.

Berdasarkan Gambar 3 dapat disimpulkan bahwa 3 urutan rata-rata jenis cacat (CTQ) yang 


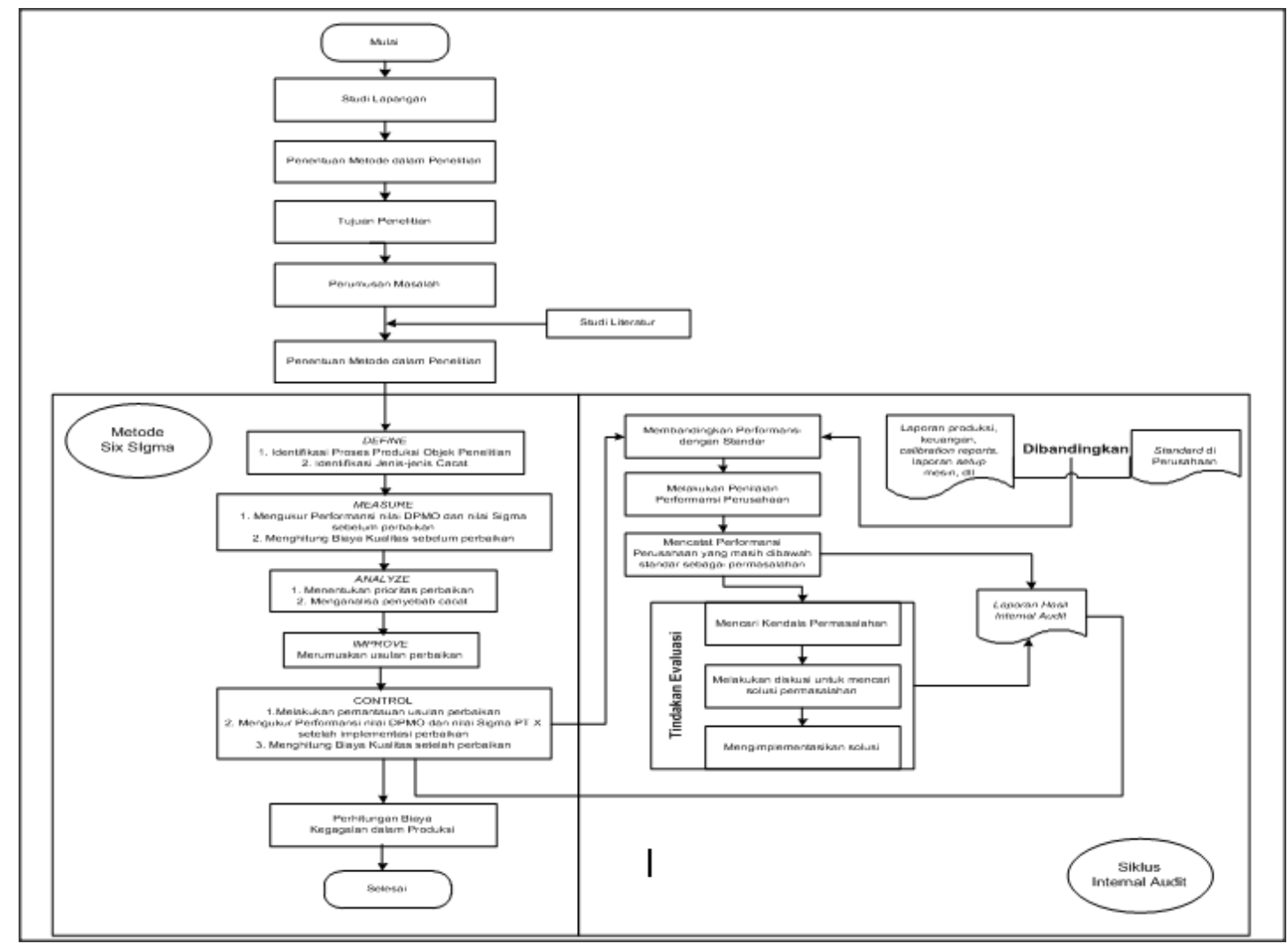

Gambar 2: Bagan Metodologi Penelitian

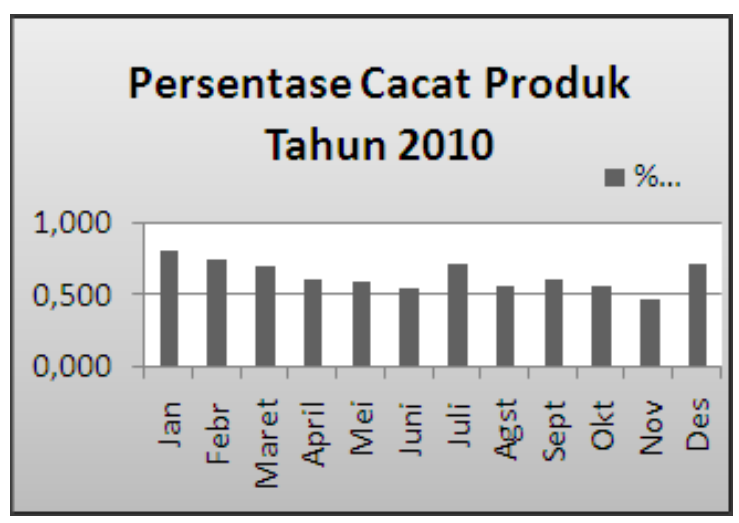

Gambar 3: Persentase Cacat Produk Tahun 2010

paling sering terjadi pada PT X adalah jahitan putus (418), ukuran garment tidak sesuai spesifikasi $(415,5)$, dan warna pada panel garment belang $(380,25)$.

Keterangan:

1. Warna pada panel garment belang,

2. Aksesoris yang dipasang salah,

3. Aksesoris pada garment kurang kuantitasnya,

4. Ukuran garment tidak sesuai spesifikasi,

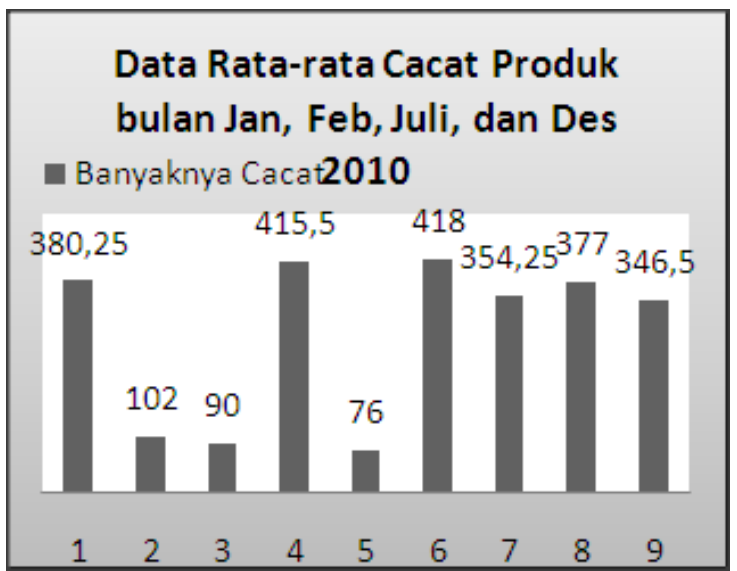

Gambar 4: Rata-rata Cacat Produk Bulan Januari, Februari, Juli, dan Desember 2010

5. Interlining terkelupas, kancing lepas, ditemukan batu (untuk efek washing / stonewash) tertinggal didalam kantong (pocket),

6. Jahitan Putus,

7. Jahitan Longgar,

8. Jahitan Loncat, dan

9. Jahitan Meleset 


\subsubsection{Analisa Penyebab Masalah}

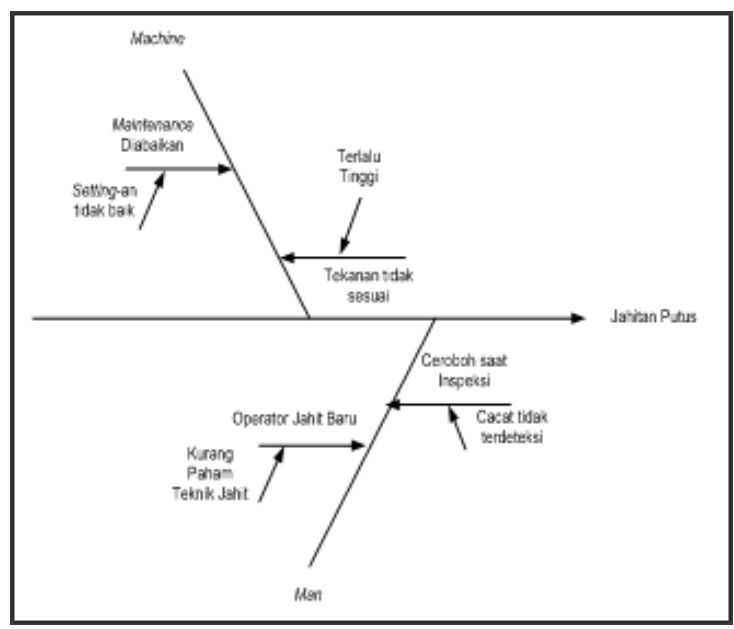

Gambar 5: Fishbone Diagram untuk Jahitan Putus

\subsection{Tahap Improve}

Pada Tabel 6 ditampilkan perhitungan RPN dengan Metode Failure Mode and Effect Analysis (FMEA) untuk menentukan akar penyebab jahitan putus, ukuran garment tidak sesuai spesifikasi, dan warna pada panel garment belang yang terjadi pada PT X.

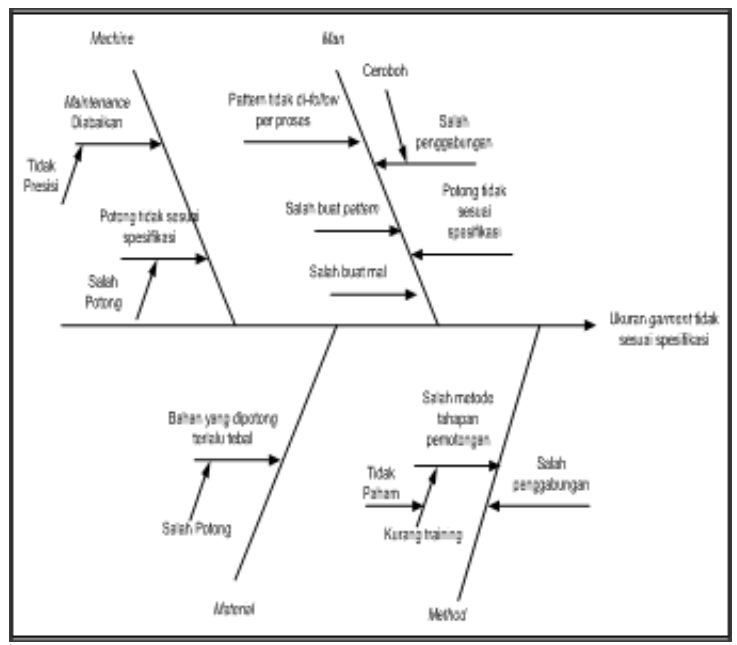

Gambar 6: Fishbone Diagram untuk Ukuran Garment Tidak Sesuai Spesifikasi

Sedangkan usulan perbaikan untuk 3 CTQ yang paling sering terjadi tersebut ditampilkan pada Tabel 7.

\subsubsection{Performansi Perusahaan Setelah Imple- mentasi Perbaikan}

Total Jumlah Cacat $=2.056$

Jumlah Unit Periksa $=91.719$ unit

$$
\begin{gathered}
D P M O=\frac{\text { jumlahdefect }}{\text { Peluangcacat }(C T Q) \times \text { jumlahsample }} \\
x 1.000 .000 \\
D P M O=\frac{2056}{9 \times 91719} \times 1.000 .000=2491
\end{gathered}
$$

Nilai sigma $=4,308 \sigma$

\subsection{Tahap Control}

Pada tahap control yang dilakukan adalah proses pengendalian agar cacat produk yang terjadi pada PT X dapat diminimasi. Tahap pengendalian yang dilakukan adalah melakukan internal audit dalam frekuensi maksimal 2 minggu sekali. Berdasarkan analisa diketahui bahwa banyak produk cacat yang terjadi pada PT X umumnya disebabkan oleh internal audit yang tidak dilakukan secara berkala, sehingga sering sekali di perusahaan banyak performansi yang tidak sesuai dengan standar. Dengan internal audit yang dilakukan secara berkala selama 2 minggu sekali diharapkan perusahaan mampu mengurangi cacat produk dan segera mengambil tindakan jika ternyata terdapat hal-hal yang terjadi di produksi tidak sesuai dengan standar yang telah ditetapkan oleh tim manajemen PT X dalam SOP (Standard Operating Procedure).

\subsection{Biaya Kegagalan dalam Produksi (Biaya Kualitas)}

\subsubsection{Sebelum Implementasi}

Rata-rata Unit Scrap per bulan $=68$ unit Rata-rata Unit Rework per bulan $=2.249$ unit

Biaya Scrap $=\operatorname{Rp} 6.990 .536,00$

Biaya Rework $=$ Rp 220.562.511,10

\subsubsection{Setelah Implementasi}

Rata-rata Unit Scrap per bulan $=49$ unit Rata-rata Unit Rework per bulan $=1.020$ unit

Biaya Scrap $=\operatorname{Rp} 5.037 .298,00$

Biaya Rework $=$ Rp 104.740.223,20

Penurunan Biaya Kegagalan dalam Produksi (Biaya Scrap) 
Implementasi Metode Six Sigma dan Internal Audit dalam Menjamin Kualitas Produk Pada PT X untuk Mengefisiensikan Biaya Kualitas

Tabel 6: FMEA worksheet untuk menentukan akar penyebab 3 CTQ yang menjadi prioritas

\begin{tabular}{|c|c|c|c|c|c|c|c|}
\hline No & CTQ & $\begin{array}{c}\text { Faktor yang } \\
\text { Mempen- } \\
\text { garuhi }\end{array}$ & Penyebab & Sev & Occ & Det & RPN \\
\hline \multirow{4}{*}{1} & \multirow{4}{*}{ Jahitan Putus } & \multirow[t]{2}{*}{ Machine } & $\begin{array}{l}\text { Maintenance } \\
\text { Diabaikan }\end{array}$ & 6 & 7 & 5 & 210 \\
\hline & & & $\begin{array}{l}\text { Setting Tidak } \\
\text { Optimal }\end{array}$ & 8 & 8 & 7 & 448 \\
\hline & & \multirow{2}{*}{ Man } & Ceroboh & 3 & 2 & 4 & 24 \\
\hline & & & Operator Baru & 3 & 4 & 4 & 48 \\
\hline \multirow{6}{*}{2} & \multirow{6}{*}{$\begin{array}{c}\text { Ukuran } \\
\text { Garment } \\
\text { Tidak Sesuai } \\
\text { Spesifikasi }\end{array}$} & \multirow[t]{2}{*}{ Machine } & $\begin{array}{l}\text { Maintenance } \\
\text { Diabaikan }\end{array}$ & 7 & 7 & 8 & 392 \\
\hline & & & Salah Potong & 8 & 5 & 9 & 360 \\
\hline & & \multirow[t]{2}{*}{ Man } & $\begin{array}{c}\text { Salah Mal dan } \\
\text { Pattern }\end{array}$ & 8 & 6 & 8 & 384 \\
\hline & & & Salah Penggabungan & 4 & 3 & 3 & 36 \\
\hline & & Material & Bahan Terlalu Tebal & 2 & 1 & 5 & 10 \\
\hline & & Method & $\begin{array}{l}\text { Salah Metode } \\
\text { Pemotongan }\end{array}$ & 8 & 3 & 9 & 216 \\
\hline \multirow{5}{*}{2} & \multirow{5}{*}{$\begin{array}{c}\text { Warna pada } \\
\text { Panel } \\
\text { Garment } \\
\text { belang }\end{array}$} & Machine & $\begin{array}{c}\text { Maintenance } \\
\text { Diabaikan }\end{array}$ & 3 & 6 & 4 & 72 \\
\hline & & Man & $\begin{array}{c}\text { Salah numbering } \\
\text { panel }\end{array}$ & 2 & 2 & 5 & 20 \\
\hline & & Material & $\begin{array}{c}\text { Material Kain tidak } \\
\text { sesuai spesifikasi }\end{array}$ & 6 & 3 & 7 & 126 \\
\hline & & \multirow{2}{*}{ Method } & Salah me-lotkan kain & 4 & 7 & 8 & 224 \\
\hline & & & $\begin{array}{c}\text { Pengendalian } \\
\text { inventory tidak jelas }\end{array}$ & 4 & 4 & 5 & 80 \\
\hline
\end{tabular}

Tabel 7: Hasil penelitian mengenai industri yang melakukan internal audit (CBOK, 2010)

\begin{tabular}{|c|c|c|c|}
\hline No & CTQ & $\begin{array}{c}\text { Akar } \\
\text { Penyebab }\end{array}$ & Usulan Perbaikan \\
\hline 1 & Jahitan Putus & $\begin{array}{c}\text { Setting Tidak } \\
\text { Optimal }\end{array}$ & $\begin{array}{c}\text { Perancangan } \\
\text { Eksperimen }\end{array}$ \\
\hline 2 & $\begin{array}{c}\text { Ukuran Garment } \\
\text { Tidak Sesuai } \\
\text { Spesifikasi }\end{array}$ & $\begin{array}{c}\text { Maintenance } \\
\text { Diabaikan }\end{array}$ & Maintenance berkala \\
\hline 3 & $\begin{array}{c}\text { Warna pada Panel } \\
\text { Garment belang }\end{array}$ & $\begin{array}{c}\text { Salah } \\
\text { melotkan kain }\end{array}$ & $\begin{array}{c}\text { Pemeriksaan lot kain } \\
\text { sebelum dikirim ke } \\
\text { bagian Cutting }\end{array}$ \\
\hline
\end{tabular}

$=\operatorname{Rp} 6.990 .536,00-\operatorname{Rp} 5.037 .298,00$

$=\operatorname{Rp} 1.953 .238,00$

(Biaya Rework)

$=\operatorname{Rp} 220.562 .511,10-\operatorname{Rp} 104.740 .223,20$

$=\operatorname{Rp} 115.822 .287,90$

Penghematan $=\operatorname{Rp} 117.775 \times 525,90$

$=1.145,65$ unit

$=1.145$ unit berkualitas

Pada penelitian ini diperhitungkan biaya kualitas untuk mengetahui biaya kualitas yang dikeluarkan PT X, terutama biaya yang terkait dengan biaya kegagalan dalam produksi. Dari hasil perhitungan diketahui bahwa jika perusa- haan mengimplementasikan solusi perbaikan, maka perkiraan keuntungan yang diperoleh PT $X$ adalah Rp 117.775 x 525,90 atau jika dikonversi ke satuan unit adalah 1.145 unit yang berkualitas baik yang sampai ke tangan konsumen.

\section{Hasil dan Pembahasan}

Dalam penelitian digunakan metode Six Sigma untuk mengetahui performansi perusahaan terkait dengan kualitas produk yang diproduksi pada PT X. Berdasarkan pengolahan data diperoleh nilai DPMO dan nilai sigma di awal penelitian (sebelum implementasi perbaikan) adalah 6.429 dan 3,987 $\sigma$. Nilai DPMO ini merepresentasikan bahwa PT $X$ masih menghasilkan cacat produk sebanyak 6.429 dari 1.000 .000 kesempatan produk yang dihasilkan. Jumlah ini tentu tidak signifikan, namun jika ini tidak dilakukan perbaikan maka lama kelamaan kualitas produk dapat menjadi prioritas kedua karena perusahaan lebih mengutamakan keuntungan dari segi nominal materi saja. Hal ini yang kemudian menjadi salah karena perusahaan yang baik adalah perusahaan yang mengutamakan kualitas dibandingkan kuantitas produksi. Oleh sebab 
itu dalam penelitian dilakukan analisa dan diberikan usulan berbaikan untuk menurunkan nilai DPMO dan menaikkan nilai Sigma. Dari hasil pengolahan data setelah implementasi perbaikan, diperoleh hasil bahwa nilai DPMO dan nilai sigma menjadi 2.491 dan 4,308 $\sigma$. Nilai DPMO menurun sekitar 3.938, sedangkan nilai Sigma naik sekitar $0,321 \sigma$.

Dalam tahapan Six Sigma, pada tahapan Control dilakukan internal audit. Program internal audit ini dimaksudkan untuk melakukan pengawasan terhadap konsistensi pengendalian proses, pengendalian dokumen, pengendalian peraturan, dan pengendalian kebijakan yang ada pada PT X untuk menjamin SMM (Sistem Manajemen Mutu) yang baik di perusahaan. Kondisi perusahaan sebelum implementasi perbaikan adalah SMM tidak cukup baik karena banyak hal-hal penting seperti pengendalian report, SOP, maintenance, dan lain-lain diabaikan pelaksanaannya. Hal inilah yang dirasa mengganggu pencapaian SMM yang baik pada PT X. Pada PT X sering kali external audit yang dilakukan oleh vendor sebanyak 1 tahun sekali justru menjadi tolak ukur sistem atau keadaan perusahaan yang perlu diperbaiki karena tidak sesuai dengan standar. Dengan melihat hasil external audit ini tidak tepat, karena hal-hal yang harus diperbaiki di perusahaan justru ditemukan oleh konsumen (vendor). Sebagai bentuk antisipasi atau pengendalian SMM sebaiknya melakukan internal audit maksimal 2 minggu sekali untuk proses pengendalian SMM agar lebih terstruktur dan segera teridentifikasi jika terdapat dokumen, report, dan lain-lain yang tidak sesuai standar sehingga dapat langsung diambil tindakan.

\section{Kesimpulan}

Dari hasil penelitian dapat disimpulkan bahwa terdapat 3 jenis cacat yang paling sering terjadi pada PT X, diantaranya: jahitan putus, ukuran garment tidak sesuai spesifikasi, dan warna pada panel garment belang. Ketiga CTQ ini kemudian dicari akar permasalahan yang menjadi penyebab utama permasalahan-permasalahan dengan menggunakan Metode FMEA sebagai dasar dalam penentuan usulan perbaikan untuk mengurangi jumlah cacat yang terjadi pada PT X. Rekapitulasi usulan-usulan perbaikan untuk 3 CTQ tersebut ditampilkan pada Tabel VII. Dalam perancangan eksperimen diperoleh faktor tekanan yang optimal untuk proses penjahitan dengan mesin jahit jarum 1 adalah 0,5. Tekanan ini paling sedikit mengakibatkan jahi- tan putus, oleh sebab itu dapat disimpulkan bahwa tekanan optimal untuk mesin jahit jarum 1 adalah 0,5 .

Biaya kualitas, khususnya biaya kegagalan dalam produksi yang dikeluarkan perusahaan sebelum melakukan perbaikan adalah $\mathrm{Rp}$ 227.553.047,10 (meliputi biaya scrap dan biaya rework). Sedangkan biaya kegagalan dalam produksi (meliputi biaya scrap dan biaya rework) setelah implementasi perbaikan adalah $\mathrm{Rp}$ 109.777.521,20. Dengan kata lain setelah menerapkan internal audit untuk melakukan pengendalian report, SOP, maintenance, dan lainlain maka perusahaan mampu mendapat keuntungan atau penghematan Rp 117.775.525,90 atau jika dikonversi ke nilai unit, penghematan itu setara dengan mampu menghasilkan produk berkualitas dan dijual ke tangan konsumen sebanyak 1.145 unit. Tentu hal ini sangat menguntungkan bagi perusahaan, oleh sebab itu sangat penting sekali dilakukan interval audit minimal setiap 2 minggu sekali untuk menjaga SMM perusahaan berjalan dengan baik sehingga memberikan keuntungan bagi perusahaan dan mampu meningkatkan loyalitas konsumen. 


\section{Daftar Pustaka}

Ariani, D.W. (2002). Manajemen Kualitas : Pendekatan Sisi Kualitatif, Proyek Peningkatan Penelitian Pendidikan Tinggi Direktorat Jenderal Pendidikan Tinggi Departemen Pendidikan Nasional. Yogyakarta.

CBOK. (2010). Yass Alkafaji, Shakir Hussain, Ashraf Khallaf, Munir A. Majdalawieh., A Component of the CBOK Study: The IIAs Global Internal Audit Survey Characteristics of an Internal Audit Activity - Report I. The Institute of Internal Auditors Research Foundation. ISBN 978-0-89413-695-5.

Dermawan, D. (2007). Studi Aplikasi Pengendalian Mutu Produksi Kantong Semen pada Unit Sewing Bag Divisi Pabrik Kantong PT Semen Padang. Tesis. Medan.

Gaspersz, Vincent. (1997). Manajemen Kualitas Dalam Industri Jasa, PT Gramedia Pustaka Utama. Jakarta.

Gaspersz, Vincent. (2003). Total Quality Management. PT Gramedia Pustaka Utama. Jakarta.

Gaspersz, Vincent. (2006). Total Quality Management: Untuk Praktisi Bisnis dan Industri. PT. Gramedia Pustaka Utama. Jakarta.

Gaspersz, V. (2008). Total Quality Management, PT Gramedia Pustaka Utama. Jakarta.

Kotler, Philip. (2003).Marketing Management. New Jersey.Prentice Hall. Jakarta.

Nasution, M.N. (2004). Manajemen Mutu Terpadu (Total Quality Management). Ghalia Indonesia. Jakarta.

Permata, Gita. (2012). Model Pendekatan Siklus Internal Audit dalam Hubungannya dengan Aktivitas External Audit dan Faktor-faktor Lingkungannya, Seminar Nasional Inovasi Rekayasa Teknologi (SNIRT) Ke-1 Tahun 2012, Cirebon, Indonesia, 185-199.

Xiangdong, W. (1997).Development Trends and Future Prospects of Internal Audit. Journal of Managerial Auditing, 12 (4), pp. 200204. 